\title{
Makna Komunitas Literasi Bagi Masyarakat Kota Sumenep Dalam Pembangunan SDM
}

\author{
Akbar Mawlana \\ Departemen Sosiologi, FISH, Universitas Negeri Surabaya \\ Jl. Lidah Wetan, Surabaya (60213), Jawa Timur, Indonesia \\ kaconkalan@gmail.com
}

Received : 29-04-2021, Revision : 19-06-2021, Acceptance : 30-06-2021, Published Online : 30-06-2021

\begin{abstract}
Abstrak
Keberadaan komunitas literasi terus mengalami perkembangan. Secara kritis, komunitas literasi hadir untuk memajukan aktivitas literasi. Pada perkembangannya, kehadiran komunitas literasi bukan hanya berada di kota besar. Komunitas literasi semakin eksis di berbagai kota di Indonesia, salah satunya berada di Kabupaten Sumenep. Eksistensi dari komunitas literasi di Sumenep memiliki pengaruh yang signifikan, karena memiliki tujuan yang positif. Namun, setiap masyarakat Sumenep memiliki cara pandang yang berbeda dalam menilai kehadiran komunitas literasi. Oleh karenanya, penelitian ini bertujuan untuk mengetahui makna komunitas literasi bagi masyarakat kota Sumenep dalam pembangunan SDM. Penelitian menggunakan metode kualitatif dengan pendekatan fenomenologi constitutive. Fenomenologi costitutive mengkonfigurasikan kesadaran individu berdaasrkan pengalamannya dalam ralitas sosial. Teknik pengumpulan data menggunakan wawancara, observasi, dan dokumentasi. Pengambilan subjek penelitian menggunakan teknik purposive. Dengan begitu, subjek penelitian adalah masyaraka yang berada di kecamatan Kota Sumenep. Alasannya adalah kecamatan Kota Sumenep menjadi pusat dari berbagai aktivitas komunitas literasi di Sumenep. Perspektif teori dari Herbert Blummer mengenai interaksionisme simbolik menjadi alat analisa dalam fenomena ini. Dengan menggunakan teori Blummer diperoleh 3 makna komunitas literasi bagi masyarakat Kota Sumenep. Pertama, komunitas literasi bermakna sebagai tempat untuk melahirkan penulis. Kedua, bermakna membentuk kaum intelektual. Ketiga, memiliki makna sebagai tempat mempebaiki minat baca. Ketiga pemaknaan tersebut, terjadi melalui proses interaksi, melakukan penafsiran, dan membentuk objek sosial.
\end{abstract}

Kata Kunci: Komunitas literasi, Masyarakat Sumenep, Makna komunitas Literasi.

Abstract

The existence of the literacy community continues to develop. Critically, the literacy community exists to advance literacy activities. The presence of the literacy community is not only in big cities. literacy community increasingly exist in various cities in Indonesia, one wich in Sumenep regency. Excistence of the literacy community in Sumenep has a significant influence, because it has a positive purpose. However, each Sumenep society has a different perspective in assesing the presence of the literacy community. Therefore, this study aims to determine the meaning of the literacy community for the peoplo of Sumenep in developing human resources. This research uses a qualitative method with a constitutive phenomenologyl. Constitutive phenomenolgy configures individual consciousness based on his experience in social reality. Data collection techniques using interviews, observation, and documentation. Taking research subjects using a purposive technique. The research subjects are people who are in the Sumenep City subdistrict. The reason is that sub-dictrict of Sumenep City is the center of various literacy community activities in Sumenep. Herbert Blummer theoretical perspective on symbolic interactionisme becomes an analytical tool in this phenomenon. By using Blummers theory 3 meaning of literacy community are abtained for the society of Sumenep City. First, the literacy community is meaningful as a place to give birth to writers. Second, it means forming inttelectuals. Third, it has meaning as a place to improve reading interest. Three meanings occur through the process of interaction, interpreting, and forming social objetcs.

Keywords: Literacy community, Sumenep society, The meaning of literacy community. 


\section{PENDAHULUAN}

Literasi menjadi objek yang esensial dalam kehidupan sosial. Melalui literasi dapat mempertajam logika, rasa , dan imajinasi (Lie, dkk., 2008: viii). Dengan begitu, aktivitas literasi kerap menjadi wacana pengembangan di sekolah. Riset Salma \& Mudzanatun (2019) memperlihatkan gerakan literasi di sekolah memberikan pengaruh fundamental terhadap minat baca peserta didiknya. Perkembangan aktivitas literasi di Indonesia terus mengalami perkembangan. Menurut Ea (2020: 104-106) telah terjadi pembentukan arus baru dalam dunia literasi di Indonesia. Hadirnya orang terdidik di berbagai daerah Indonesia menjadi penyebab utama terjadi perubahan arus literasi. Sebab, semakin banyak orang luar Pulau Jawa menimba ilmu di Jawa atau luar negeri. Selain itu, terjadinya progresifitas literasi di Indonesia juga disebabkan oleh kemajuan teknologi. Perkembangan teknologi memberikan pengaruh dalam membawa perubahan subkultur realitas sosial (Barker, 2006: 155). Terakutalisasikan dari kehadiran aplikasi IPUSNAS yang bisa membantu masyarakat untuk mengakses sumber bacaan dengan mudah.

Kendati demikian, kemudahan masyarakat dalam melakukan literasi tidak serta-merta dapat mendobrak minat baca masyarakat. Penelitian dari PISA menunjukkan jika minat baca masyarakat Indonesia masih rendah (Wahyuni, 2009). Negara Indonesia berada dalam 10 negara terendah perihal aktivitas membaca. Terdapat dua faktor yang membuat minat baca masyarakat Indonesia rendah. Pertama, masyarakat Indonesia lebih senang meluangkan waktu luangnya dengan aktivitas negatif. Studi Asniar, dkk. (2020) memperlihatkan jika remaja di sekolah menggunakan waktu luangmya dengan bergosip dengan sesama temannya. Kebanyakan remaja enggan untuk memanfaatkan sebagian waktunya untuk membaca (Susanti \& Santi, 2019). Kedua, masyarakat Indonesia lebih menggemari komunikasi lisan dibandingkan dengan komunikasi melalui tulisan. Masyarkat Indonesia lebih menggemari sinema yang diambil melalui video, daripada harus membaca tulisan (Heryanto, 2019).

Rendahnya literasi masyarakat Indonesia menjadi latar belakang berdirinya Taman Bacaan Masyarakat (TBM). Kehadiran TBM menjadi alternatif masyarakat yang ingin membaca buku, tetapi, tidak bisa membeli buku karena harga belinya yang mahal. Oleh karenanya, TBM hadir di ruang yang mudah terjangkau untuk memudahkan masyarakat dalam meminjam dan membaca buku (Haklev, 2008). Penelitian Kurniasari \& Arfa (2020) memperlihatkan konsep pengembangan literasi dari komunitas Pustaka Warga di Semarang dengan cara menjejalkan bacaan gratis di tempat kumpul masyarakat. Keberadaan TBM dikelolah dengan konsep merakyat. Artinya, kehadiran TBM dimulai dari rakyat dan juga dimanfaatkan oleh rakyat (Misriyani \& Mulyono, 2019). Sehingga, keberadaan TBM kian 
menjamur di Indonesia. Menurut data dari Kemendikbud saat ini ada 4415 TBM. Apabila dirinci kembali, ada 3 provinsi dengan jumlah TBM paling banyak, antara lain: Jawa Barat (587), Jawa Tengah (477), dan Jawa Timur (754). Faktor utama pesatnya perkembangan TBM di Jawa Timur adalah munculnya kesadaran jika kehadiran TBM dapat membantu pengembangan Sumber Daya Manusia (SDM) (Ginanjar, 2019).

Kesadaran tersebut juga ditunjukkan dari berbagai kalangan masyarakat di Sumenep. Sumenep merupakan salah satu daerah yang menjadi pusat pendidikan di Madura. Hal itu terkonfigurasikan dengan pesatnya lembaga pendidikan sejak masa kolonial (Hefni, 2019). Tidak mengherankan apabila komunitas literasi di Sumenep semakin berkembang. Ach. Fauzi selaku Wakil Bupati Sumenep tahun 2019 mengatakan bahwa dirinya mengapresiasi kehadiran komunitas literasi dalam rangka memperkuat SDM dan juga memberikan ruang seluas-luasnya agar komunitas literasi bisa dibangun dengan mudah (Setapu, 2019).

Salah satu komunitas literasi di Sumenep yang memiliki nama besar adalah Rumah Literasi. Secara histori, kehadiran Rumah Literasi baru berdiri pada tahun 2016. Para pendirinya adalah guru yang berada di Sumenep Tujuan dari pendirian Rumah Literasi adalah ingin mengembangkan minat membaca masyarakat Sumenep, terkhusus generasi mudanya (Rumah Literasi Sumenep, 2016). Selain itu, kehadiran komunitas literasi di Sumenep juga bertujuan untuk mengenali kembali kebudayaan tradisional kepada anak mudanya (Supriyadi, 2021). Secara umum, kehadiran komunitas literasi dapat menjadi wadah untuk mengembangkan SDM di Sumenep.

Namun, keberadaan komunitas literasi membentuk persepsi masing-masing dari masyarakat Sumenep. Masyarakat ada yang memandang kehadirannya belum membawa perubahan secara signifikan (Maduraexpose.com, 2016). Tetapi, juga ada yang menilai kehadiran komunitas literasi mampu membawa kemajuan dalam pembangunan SDM (Hartono, 2020). Terjadinya perbedaan cara pandang, karena masyarakat Sumenep memiliki pandangan beragam mengenai kehadiran komunitas literasi. Bagi Blumer (1984: 79) individu sering melakukan pendefinisian melalui proses interpretasi yang pada akhirnya menghasilkan sebuah pemaknaan. Berangkat dari permasalahan tersebut, peneliti tertarik untuk melihat bagaimana makna komunitas literasi bagi masyarakat Kota Sumenep dalam pembangunan SDM?

\section{Metode Penelitian}

Penelitian inni menggunakan metode kualitatif. Menurut Sugiyono (2020: 3) penelitian kualitatif bertujuan untuk menemukan makna dalam suatu fenomena. Hal itu, berkesinambungan dengan penelitian ini yang ingin memahami makna komunitas literasi bagi 
masyarakat Sumenep. Pendekatan penelitian menggunakan fenomenologi constitutive. Fenomenologi constitutive melihat pengetahuan berasal dari dalam subjek (Husserl, 2020: ii). Sehingga, pemahaman masyarakat selalu berkelindan dengan realitas sosialnya (Salim, 2006). Melalui pendekatan fenomenologi constitutive berguna untuk memahami pengalaman masyarakat dalam memberikan makna dalam kehidupan kesehariannya.

Lokasi penelitian berada di kecamatan Kota, Kabupaten Sumenep. Alasannya adalah mayoritas keberadaan komunitas literasi berada di kecamatan Kota. Berbagai kegiatan komunitas literasi juga lebih berorientasi di Kota Sumenep, terutama di Taman Bunga. Dengan begitu, lokasi penelitian akan lebih tepat dilaksanakan di Kota Sumenep. Ditambah lagi dengan karakteristik masyarakat yang berada di kota lebih menggemari menggunakan waktu luangnya bersantai di Taman Bunga.

Pengumpulan data menggunakan observasi, wawancara, dan dokumentasi. Proses wawancara menggunakan bentuk wawancara tidak terstruktur. Artinya, dalam pengumpulan data tidak memakai isntrumen pertanyaan secara penuh (Jaya, 2020). Wawancara dilakukan secara fleksibel dan santai dengan tetap mengarahkan topik penelitian sesuai garis besar dari instrumen pertanyaan. Observasi menggunakan partisipasi lengkap, yakni peneliti dalam melakukan observasi terlihat wajar dan terlibat penuh terhadap subjek penelitian (Sugiyono, 2020: 108). Posisi peneliti sebagai orang Sumenep memberikan kemudahan dalam proses observasi. Hanya saja, peneliti tetap memberikan batasan untuk menghasilkan data yang objektif. Data dokumentasi berasal dari catatan harian dan cerita dari pengalaman informan.

Analisis data menggunakan model dari Miles dan Huberman yang terdiri dari pengumpulan data, reduksi data, penyajian data, dan penarikan kesimpulan (Jaya, 2020). Pengumpulan data yang berasal wawancara, observasi, dan dokumentasi, harus dilakukan reduksi data. Tujuannya adalah untuk mengelompokkan data agar sesuai dengan tujuan penelitian. Lantaran, tidak semua data yang terkumpul memiliki korelasi dengan topik pembahasan (Creswell, 2019). Selanjutnya, pemamparan penyajian data berbentuk naratif. Kemudian, penarikan kesimpulan berasal dari analisis data.

\section{Pembahasan}

\section{Makna akan melahirkan penulis}

Komunitas literasi di Sumenep bukan hanya sekadar menyediakan buku bacaan secara gratis kepada masyarakat. Kehadiran komunitas literasi juga ikut ambil peran dalam kegiatan literasi lainnya, seperti menulis. Seharusnya, kegiatan literasi juga berkelindan antara kegiatan meningkatkan minat baca masyarakat dan juga kemampuan menulis. Modal membaca tidak 
cukup untuk menggerakkan kegiatan literasi secara berkelanjutan. Oleh sebab itu, kegiatan literasi juga harus difokuskan kepada aktivitas menulis.

Pada hakikatnya, kegiatan menulis merupakan aktivitas yang memiliki tujuan baik. Sebab, melalui tulisan gagasan seseorang akan tersampaikan dan dibaca oleh banyak orang. Lebih dari itu, kegiatan menulis juga menjadi modal untuk membentuk tindakan progresif yang bisa merubah tatanan sosial. Sebagaimana yang sudah dilakukan oleh Benda (1999) melalui tulisannya tentang pengkhianatan kaum cendikiawan yang dapat merubah wajah dunia.

Kegiatan menulis, tidak selamanya menarik minat banyak kalangan. Penyebabnya adalah menulis dianggap sebagai tindakan yang sulit (EA, 2020). Persepsi semacam itu, juga terbentuk dalam pemikiran anak muda di Sumenep. Anak muda di Sumenep menganggap tindakan menulis sebagai tindakan yang membosankan dan membuat pusing. Kondisi tersebut, menyebabkan jumlah penulis yang ada di Sumenep mengalami stagnasi. Apabila dikaji ulang, penulis di Sumenep yang mampu melalangbuana di tingkat Nasional sudah berusia tidak muda, seperti Zawai Imron dan Edi A.H Iyabenu.

Oleh karenanya, dengan kondisi anak muda di Sumenep yang mempersepsikan menulis sebagai tindakan yang rumit dan sulitnya regenerasi penulis di Sumenp - membuat komunitas literasi berinisatif melakukan pendobrakan. Bentuk pendobrakannya melalui pelatihan menulis. Pelatihan menulis diharapkan mampu merangsang keinginan anak muda di Sumenep untuk melakukan aktivitas menulis.

Alex mengakui pertama kali memperdalami ilmu menulis dari komunitas literasi. Sebenarnya, Alex sudah suka menulis sejak SMP. Namun, tidak terlatih dengan baik. Sehingga, dirinya merasa tertantang untuk ikut pelatihan menulis di beberapa komunitas literasi. Penilaian Alex mengenai pelatihan menulis di komunitas literasi sangat baik. Sebab, dalam pelatihannya, bukan hanya dilakukan 1x. Akan tetapi, dilakukan selama berbulan-bulan. Bahkan, pembimbingnya mengarahkannya secara mendasar dan telaten.

Berbeda dengan Deky. Deky merupakan remaja yang tidak mengikuti pelatihan menulis di komunitas literasi. Namun, dirinya tertarik untuk mengikuti pelatihan menulis di sekolah. Sebab, Deky mengetahui pelatihan menulis di sekolah lebih nyaman. Deky mengetahuinya dari temannnya yang sudah mengikuti pelatihan menulis. Temannya pernah menilai bahwa pelatihan menulis di sekolah lebih intensif. Oleh sebab itu, Deky tertarik untuk mengikuti rekan temannya.

Selain itu, untuk mengembangkan kemampuan dan meregenerasi penulis di Sumenep, komunitas literasi tidak hanya melakukan kelas menulis. Terkadang, komunitas literasi juga melakukan program lainnya. Yakni, melakukan fasilitas dalam pembuatan majalah. Majalah 
dianggap sebagai media yang dapat merepresentasikan kondisi sosial. Mengingat dari kehadiran media tidak pernah lepas dengan bahasa. Bahasa dalam perpektif postmodern dianggap tidak netral. Melalui bahasa, akan membentuk representasi kehidupan sosial yang bisa digunakan untuk melakukan resistensi (Cannella \& Viruru, 2004).

Melalui pemberian fasilitas pembuatan majalah, dapat menjadi pemantik bagi anak muda Sumenep untuk berpikir kritis. Kemampuan berpikir kritis dilakukan melalui dua karya di majalah. Pertama, karya sastra melalui puisi dan cerpen. Kedua, melalui penulisan esai. Kedua bentuk tersebut juga tersaji dalam pembuatan majalah yang diinisiasi oleh beberapa komunitas literasi.

Menurut Alex, selaku anak muda yang juga mengikuti kelas pembuatan majalah di komunitas literasi, menejelaskan bahwa ada pelayanan bimbingan dengan baik dalam pebuatan majalahnya. Saat pembuatan majalah, fasilitator membimbing secara bertahap. Tahap pertama adalah dilatih untuk menemukan gagasan yang unik dan baru. Tahap kedua, dilatih untuk memadukan antara ide dan data yang ada. Tahap ketiga dilakukan pembekalan untuk menuliskan ide secara padat.

Lebih dari itu, tidak jarang komunitas literasi juga berkolaborasi dengan sekolah SMA Negeri yang ada di Sumenep. Tujuannya adalah agar murid di SMA dapat memiliki bekal. Proses kolaborasinya dilakukan dengan cara mikro. Artinya, langsung melakukan komunikasi kepada guru. Biasanya, guru yang diajak berkomunikasi adalah guru yang memegang ekstrakulikuler Karya Ilmiah Remaja (KIR). Selanjutnya, guru tersebut mengajak muridnya untuk mengikuti pelatihan di komunitas literasi. Cara semacam itu menunjukkan adanya tindakan komunikatif yang bersifat interaktif dalam ruang publik (Ramin, 2017).

Tendensi tindakan komunitas literasi yang gencar untuk menghasilkam penulis anak muda di Sumenep berlangsung melalui interaksi dengan masyarakat luas. Sebagaimana, interaksinya bersifat vertikal dan horizontal. Berbeda dengan interaksi secara vertikal, terjadi kepada anggota lomunitas literasi kepada guru di sekolah. Terjadinya kedua interaksi tersebut, tanpa disadari akan membentuk sebuah pemaknaan. Sebab, dalam pemikiran Blumer masyarakat dan individu tidak bisa dipisahkan, karena keduanya saling bergantung dan berpengaruh. Kemudian, dari interaksi yang terus-meneus dilakukan akan membentuk makna yang berubah menjadi keyakinan bagi masyarakat (Wirawan, 2012).

\section{Makna Pembentukan Kaum Intelektual}

Keberadaan kaum intelektual di Sumenep juga menjadi fokus dari komunitas literasi. Intelektual dipahami sebagai orang yang memiliki kemampuan nalar kritis dan sadar akan 
permasalahan sosial (Toyibah, 2020). Oleh karenanya, keberadaan kaum intelektual diharapkan menjadi ujung tombak untuk bisa mengatasi permasalahan. Permasalahan yang ada di Sumenep cukup kompleks, baik dari segi sosial, ekonomi, budaya, dan pembangunan. Secara esensial, terdapat dua bentuk permasalahan yang mendominasi di Sumenep. Yakni, permasalahan kurangnya kesejahteraan masyarakat dan tingginya angka pernikahan dini (Rifai, 2020).

Permasalahan yang cukup pelik di Sumenep merupakan landasan utama komunitas literasi untuk menghadirkan kaum intelektual. Pada dasarnya, keberadaan kaum intelektual di Sumenep tidak sulit untuk menemukannya. Namun, untuk melakukan regenerasi adalah tindakan preventif. Apabila tidak ada tindakan preventif akan menjadi proses penyingkiran keberadaan intelektual di Sumenep.

Cara yang digunakan oleh komunitas literasi untuk menumbuhkan kaum intelektual dengan melakukan diskusi buku. Buku yang didiskusikan tidak ada aturannya. Namun, lebih diorientasikan kepada buku yang membahas tentang Sumenep atau Madura. Melalui diskusi semacam itu, diharapkan mampu melihat konstelasi permasalahan yang ada di Madura atau di Sumenep.

Bentuk proses diskusi lebih mengarah kepada seputaran budaya yang ada di Sumenep. Orientasi yang diusung lebih mengarah perihal kehidupan sosial budaya Sumenep. Anggota menilai bahwa diskusi buku tentang Sumenep dan Madura berdampaik baik. Lantaran, referensi buku mengenai Sumenep cukup sulit ditemukan. Oleh sebab itu, kehadiran diskusi buku dapat membantu untuk memahami Sumenep secara luas. Kendati demikin, informan juga mengakui tidak setiap diskusi buku; buku yang dipakai berkaitan dengan Sumenep. Ada juga buku yang membahas mengenai sejarah Nasional. Proses diskusi juga berjalan dengan seimbang. Tidak semua pemaparan dilakukan oleh pemateri. Peserta diskusi juga bisa ikut berperan untuk menukarkan gagasannya.

Kondisi diskusi yang berlangsun secara interaktif, menunjukkan bahwa komunitas literasi menerapkan konsep tinakan komunikatif dalam ruang publik (public sphere). Ruang publik terlihat dari tempat diskusi yang didatangi oleh masyarakat secara luas, tanpa ada pengecualian. Berkaitan dengan hal tersebut, Habermas menginisiasikan tindakan komunikatif sebagai tindakan yang bersifat emansipatoris (Arif, dkk., 2020).

Emansipatoris dapat terjadi ketika proses pertukaran pengetahuan bersifat sementara tidak ada yang saling mendominasi. Sebagaimana konsep pemikiran tindakan komunikatif dari Habermas. Tindakan komunikatif dapat terjadi ketika diskusi berlangsung secara setara, tanpa ada kelompok yang melakukan dominasi (Ramin, 2017). Kondisi tersebut, juga tergambarkan 
dalam proses diskusi buku yang diadakan oleh komunitas literasi. Teraktualisasikan dari konsep diskusinya yang setara dan menerima gagasan dari orang lain.Dengan demikian, akan tercipta konsensus yang berbentuk saling memahami.

Selain itu, komunitas literasi juga melakukan diskusi kecil di tempat umum. Biasanya, diskusi dilakukan ketika melakukan gelar buku. Gelar buku dilakukan dengan konsep sederhana, yakni dengan menggelar buku di tempat yang ramai masyarakat, dan masyarakat boleh membacanya secara gratis. Kemudian, ketika ada masyarakat berkeinginan untuk mebaca buku yang disediakan-salah satu anggota melakukan pendekatan kepada pembaca. Pendekatan dilakukan melalui berbagai macam bentuk. Pertama, menemani membaca. Kedua, melakukan diskusi kepada pembaca.

Sebagaimana pengakuan dari Wiya yang saat ini menempuh studi Hubungan Internasional. Wiya menilai bahwa dirinya sering pergi ke Taman Bunga. Ketika di Taman Bunga, dirinya menemukan segerombolan orang sedang menggelar buku di Taman Bunga. Kemudian, Wiya tertarik untuk menghampirinya dengan tujuan membaca buku.

Wiya mengakui, bahwa saat membaca buku, ada salah satu orang yang mendekatinya untuk mengajak diskusi. Bentuk diskusinya membahas seputar buku yang sedang dibaca. Selain itu, diskusi juga diarahkan kepada proses tanya jawab mengenai permasalahan yang dilihatnya. Menurut Wiya, proses diskusi bertendensi kepada kondisi interaksi yang seimbang.

Pemaparan yang diutarakan oleh Wiya, memperlihatkan telah terjadi proses transfer pengetahuan secara dialogis. Termanifestasikan dari praktiknya yang tidak terjebak kepada kondisi pendidikan bank. Menurut Freire (2019) pendidikan gaya bank adalah proses transfer pengetahuan yang tidak seimbang. Ketidakseimbangan tersebut, dapat terjadi karena ada individu hanya sekadar dijadikan objek keterbelengguan. Dengan adanya transfer pengetahuan yang bersifat dialogis, dapat menciptakan kondisi yang mampu melakukan transformasi sosial. Ada proses pendekatan yang bersifat non-positivistik untuk melihat suatu permasalahan.

Keberadaan komunitas literasi yang menciptakan kegiatan diskusi, baik diskusi buku atau diskusi kecil dalam menggelar buku di ruang publik akan membentuk sebuah pemaknaan. Makna yang terbentuk adalah kehadiran komunitas literasi ditafsir dapat membentuk kehadiran intelektual di Sumenep. Sebagaimana, ketiga informan juga mengartikan kehadiran komunitas literasi sebagai media yang dapat melahirkan remaja yang berpikiran kritis. Alasannya adalah kehadiran komunitas literasi telah menginisiasi tindakan yang progresif.

Pembentukan makna komunitas literasi sebagai media yang dapat membentuk kehadiran intelektual di Sumenep, tebentuk melalui proses yang panjang. Proses yang pertama adalah terjadi interaksi sesama masyarakat. Interaksi yang terjadi adalah antara masyarakat 
dengan pengurus komunitas literasi yang melakukan diskusi. Kemudian, dari hasil interaksi tersebut akan membentuk penafsiran. Pada hakikatnya, tindakan semacam itu adalah bentuk dari tindakan interaksi simbolik. Interaksi simbolik adalah tindakan yang berlangsung dari pemikiran yang terbentuk dalam kehidupan masyarakat (Ritzer, 2012).

\section{Makna memperbaiki minat baca}

Berdasarkan data yang telah diulas di latar belakang yang bersumber dari media, menyatakan bahwa kondisi masyarakat Sumenep memiliki tingkat membaca buku yang buruk. Kondisi baca yang buruk, bisa disebabkan oleh beberapa faktor. Faktor utamanya disebabkan oleh individunya sendiri.

Ada 2 faktor yang membuat informan tidak tertartik untuk membaca buku. Hal yang paling fundamental adalah malas membaca. Masyarakat menganggap jika membaca adalah tindakan yang membosankan. Rasa bosan terjadi karena aktivitas membaca buku yang mudah terbawa kepada kondisi sumpek. Sehingga, tidak mengherankan jika Deky mengakui bahwa dirinya lebih menyukai untuk membaca komik daripada membaca buku non fiksi.

Rasa malas untuk membaca yang dipaparkan oleh Deky sesuai dengan karakteristik masyarakat Indonesia. Kajian Heryanto (2019) memperlihatkan masyarakat Indonesia tidak menyukai aktivitas membaca. Masyarakat Indonesia lebih menggemari tontonan yang bergambar, seperti sinema. Salah satu alasannya adalah keberadaan gambar dapat menurunkan rasa jenuh yang terbentuk.

Wiya juga mengakui malas untuk membaca buku. Alasannya adalah dirinya akan membaca buku ketika disuruh oleh guru atau dosen untuk mereview jurnal dan buku. Wiya tetap membaca meski tidak diperintah oleh pengajarnya. Namun, intensitas membacanya sangat jarang sekali. Penyebabnya adalah lingkungan yang kurang mendukung. Pengakuan dari Wiya yang membuat dirinya jarang membaca disebabkan juga oleh lingkungan pertemanannya. Lingkungan pertemanan Wiya memang juga tidak suka membaca.

Pada hakekatnya, ketidaksukaan membaca juga disebabkan oleh lingkungan. Berdasarkan temuan dari Wahyuni (2010) lingkungan menjadi salah satu faktor yang menentukan kegeraman membaca. Apabila lingkungannya tidak mendukung, maka masyarakat juga tidak suka membaca. Akan tetapi, jika lingkungannya mendukung untuk aktivitas membaca, maka masyarakat juga akan gembar membaca.

Komunitas literasi berinisiasi untuk meningkatkan minat baca masyarakat di Sumenep. Inisiasi tersebut dilakukan dengan cara menggelar buku di ruang terbuka yang ramai masyarakat dan mendatangi sekolah. Cara yang pertama dilakukan ketika hari weekend. Saat hari weekend masyarakat Sumenep banyak yang berkumpul di Taman Bunga. Keramaian 
masyarakat, dimanfaatkan untuk menarik minat masyarakat untuk membaca. Caranya untuk menarik masyarakat adalah dengan menyediakan buku bacaan, baik fiksi atau non-fiksi dengan gratis.

Cara kedua adalah beberapa anggota literasi mendatangi bebeapa sekolah yang ada di Sumenep. Tujuannya, agar bisa mempromosikan untuk gemar membaca di tingkat pelajar. Cara yang dilakukan dengan memberikan sosialisasi. Sosialisasi dilakukan dengan pemaparan perihal pentingnya membaca untuk masa depan. Selain itu, juga dilakukan dengan memberikan sumbangan buku kepada pihak sekolah. Buku yang disumbangkan tidak menentu.

Pemanfaataan tempat umum dan sekolah untuk menumbuhkan minat baca masyarakat. Membuat literasi dimaknai sebagai komuitas yang mampu menumbuhkan minat baca masyarakat. Kehadirannya yang progresif, telah membuat masyarakat menafsirkan bahwa Komunitas literasi dapat melahirkan pemuda Sumenep yang menyukai aktivitas membaca.

\section{Kesimpulan}

Eksistensi Komunitas literasi memiliki peranan yang fundamental. Kehadirannya mampu memberikan peranan yang signifikan untuk merangsang perkembangan SDM, terkhusus kalangan remaja Sumenep. Aktivitas yang dilakukan oleh Komunitas literasi berorientasi kepada tindakan penyadaran arti penting dari literasi untuk menumbuh kembangkan menulis, membaca, dan berpikir kritis. Meskipun semua itu tidak bisa terlaksanakan dengan mudah. Sebab, masyarakat masih berasumsi jika kegiatan literasi sebagai aktivitas yang membosankan. Oleh karenanya, perlu dukungan dari berbagai pihak, seperti lembaga sekolah.

\section{Daftar Pustaka}

Arif, M., Sulthon, A., Munfarida, A., Sumardi, E., Qudsiyah, F., Misnatun, \& Muchlison, M. (2020). PENDIDIKAN POSTMODERNISME: Telaah Kritis Pemikiran Tokoh Pendidikan (kedua; R. KR, Ed.). sleman: AR-RUZZ Media.

Asniar, A., Muharam, L. O., \& Silondae, D. P. (2020). Faktor-Faktor Penyebab Rendahnya Minat Baca Siswa. Jurnal Ilmiah Bening : Belajar Bimbingan Dan Konseling, 4(1), 916. https://doi.org/10.36709/bening.v4i1.10484

Barker, C. (2006). Culture Studies: Teori dan Praktik. Yogyakarta: Kreasi Wacana.

Benda, J. (1999). Pengkhianatan Kaum Cendikiawan. Jakarta: Gramedia Pustaka Utama.

Blumer, H. (1984). Symbolic Interactionism: Perspective and Method. In Teaching Sociology (Vol. 9). https://doi.org/10.2307/1317324

Cannella, G. S., \& Viruru, R. (2004). Childhood and Postcolonization: Power, Education, and Contemporary Practice. New York: RoutledgeFalmer. 
Creswell, J. W. (2019). Reseacrh Design: Pendekatan Metode Kualitatif, Kuantitatif, dan Campuran (Keempat). Yogyakarta: Pustaka Pelajar.

EA, P. (2020). Menjadi Penulis: Menjadi Penulis Itu Tidak Sulita, Tapi Rumit. Yogyakarta: Mojok.

Freire, P. (2019). Pendidikan Kaum Tertindas (Pertama). Yogyakarta: Narasi.

Ginanjar, D. (2019, July 1). Aktifnya Aksi Komunitas Peduli Literasi Sejarah dan Budaya Surabaya. Jawa Pos.Com.

Haklev, S. (2008). MENCERDASKAN BANGSA - SUATU PERTANYAAN FENOMENA TAMAN BACAAN DI INDONESIA. University of Toronto at Scarborough.

Hartono. (2020, October 17). Gali Potensi Sumenep, Rulis Gelar Dialog Sastra dan Kepenulisan. Portal Madura.Com.

Hefni, M. (2019). ISLAM MADURA: Sebuah Studi Konstruktivisme-Strukturalis tentang Relasi Islam Pesantren dan Islam Kampung di Sumenep (M. S. Rosyid \& T. Subakti, Eds.). Batu: Literasi Nusantara.

Heryanto, A. (2019a). IDENTITAS DAN KENIKMATAN : POLITIK BUDAYA LAYAR INDONESIA (kelima). Jakarta: Kepustakaan Populer Gramedia.

Heryanto, A. (2019b). IDENTITAS DAN KENIKMATAN: Politik Budaya Layar Indonesia (Kelima). jakarta: Kepustakaan Populer Gramedia.

Husserl, E. (2020). Kuliah Paris. Yogyakarta: Antinomi.

Jaya, I. M. L. M. (2020). Metode Penelitian Kuantitatif dan Kualitatif. Yogyakarta: Quadrant.

Kurniasari, L., \& Arfa, M. (2020). Peran komunitas “pustaka sarwaga” dalam membentuk kemampuan literasi dini di kota semarang. Jurnal Ilmu Perpustakaan, 9(1), 45-54.

Lie, A., Sayoga, J. T. T., Parera, F., Josfoef, D., S.J, P. S., Tilaar, H. A. ., ... Widiyanto, P. T. (2008). Pendidikan Nasional dalam Reformasi Politik dan Kemasyarakatan. Yogyakarta: Universintas Sanata Dharma.

Maduraexpose.com. (2016, December 19). Perpusda dan Rendahnya Minat Baca di Sumenep. Maduraexpose.Com.

Misriyani, M., \& Mulyono, S. E. (2019). Pengelolaan Taman Baca Masyarakat. Journal Of Non Formal Education and Community Empowerment, 3(2), 160-172. https://doi.org/10.15294/pls.v2i1.23448

Ramin, M. M. (2017). Teori Kritis Filsafat Lintas Mazhab. Yogyakarta: Sociality.

Rifai, M. (2020). Konstruksi Sosial Da'I Sumenep Atas Perjodohan Dini Di Sumenep. Jurnal Tabligh, 21(1), 58-70. https://doi.org/10.24252/jdt.v21i1.11212

Ritzer, G. (2012). Teori Sosiologi Dari Sosiologi Klasik Sampai Perkembangan Terkahir Postmodern (Ketujuh). Yogyakarta: Pustaka Pelajar.

Rumah Literasi Sumenep. (2016). SEBUAH HANTARAN: RUMAH LITERASI SUMENEp.

Salim, A. (2006). Teori \& Paradigma Penelitian Sosial. Yogyakarta: Tiara Wacana. 
Salma, A., \& Mudzanatun. (2019). Analisis Gerakan Literasi Sekolah Terhadap Minat Baca Siswa Siswa Sekolah Dasar. MIMBAR PGSD Undiksha, 7(2), 122-127. Retrieved from http://www.mendeley.com/research/analisis-gerakan-literasi-sekolah-terhadap-minatbaca-siswa-siswa-sekolah-dasar

Setapu. (2019, September). Wabup Sumenep Dukung Penuh Gerakan Literasi. PIDPPerjuanganJatim.Com.

Sugiyono. (2020). METODE PENELITIAN KUALITATIF (S. Y. Suryandari, Ed.). Bandung: Alfabeta.

Supriyadi. (2021, April 2). Rumah Cerita Okara Kenalkan Literasi kepada Anak Sejak Dini. Rri.Co.Id.

Susanti, D., \& Santi. (2019). PEMANFAATAN TAMAN BACAAN MASYARAKAT (TBM) DALAM MENINGKATKAN MINAT BACA REMAJA (Studi Kasus di TBM Gunung Ilmu). Jurnal Comm-Edu (Community Education Journal), 2(3), 220-226. https://doi.org/10.22460/comm-edu.v2i3.2828

Toyibah, D. (2020). Perempuan Cendekia dan Tantangan Neoliberalisme (A. Arifin, Ed.). Yogyakarta: LKis.

Wahyuni, S. (2009). Menumbuhkembangkan Minat Baca Menuju Masyarakat Literat. Diksi, 16(2), 179-189. https://doi.org/10.21831/diksi.v17i1.6580

Wahyuni, S. (2010). Menumbuhkembangkan Minat Baca Menuju Masyarakat Literat. Diksi, 16(2), 179-189. https://doi.org/10.21831/diksi.v16i2.6617

Wirawan, I. . (2012). Teori - Teori Sosial Dalam Tiga Paradigma. Jakarta: Prendamedia Group. 